\title{
Empirical support of the mathematical model of the wind turbine WPI
}

\author{
S. Korneliuk \\ O.M. Beketov NUUE in Kharkiv \\ Ukraine \\ E-mail: seigerkornelyuk@gmail.com
}

\author{
P. Dmitriev \\ Mezhdurechensk \\ Russia \\ E-mail: 19ivan2010@gmail.com
}

\author{
D. Tugay \\ O.M. Beketov NUUE in Kharkiv \\ Ukraine \\ E-mail: tugaydmytro@gmail.com
}

\begin{abstract}
Experimental confirmation of mathematical models is one of the aspects of the scientific process. This article discusses the design of an experiment with a wind turbine, which was built using the mathematical model described in [7, 9] and implemented in the form of the "Aerodinama" software package [8].

The software package "Aerodinama" implements the calculation according to the "Theory of a real windmill" presented by prof. G.Kh. Sabinin in [9]. According to the calculation results, the geometric parameters of the turbine were obtained, as well as the design drawings were obtained. Then a physical model of a wind turbine was made and installed in real natural conditions. For wind turbines, a $400 \mathrm{~W}$ permanent magnet generator was selected and manufactured. Efficiency of the generator is accepted $80 \%$. For the wind turbine rotor, a three-blade propeller with a profile of blades BRUXEL 36 was used. The average annual wind speed is accepted as $3.5 \mathrm{~m} / \mathrm{s}$, and the maximum $-25 \mathrm{~m} / \mathrm{s}$.
\end{abstract}

To control wind turbine performance, a logger was developed based on the Arduino Nano microcontroller board version 3.0 and a set of several sensors. The Hall sensor KY003 Hall, ACS712 30A sensor and DS18B20 sensor. Wind speed was measured using an analog anemometer with an electromagnetic system, and was controlled by the output voltage level. Current data was collected on a memory card and duplicated on a display. Measurement step - 1 sec. The following data was tracked: wind speed; speed of the working shaft of wind turbines; voltage at the output of the rectifier unit; rectifier output current; power and temperature of the generator.

The collected data was imported into the MS EXCEL software for processing. The results of data processing are presented in the form of graphs.

The experimental data obtained confirm the accuracy of the algorithm chosen for the development of the mathematical model.

Keywords - aerodinama, wind turbine, blade, mathematical model, calculation algorithm, experiment, logger.

\section{INTRODUCTION}

Mathematical modeling is a powerful and useful tool for engineers to use in many branches of science and technology. The digital model allows calculating or verifying the parameters of the sample without making an experimental model. This approach saves a lot of time and significantly reduces the financial burden on the development of wind turbines.
A key indicator of the performance of a wind turbine is the utilization factor of wind energy. This parameter is determined by both the aerodynamic and geometric characteristics of the propeller blades. The task of the theoretical calculation of the wind turbine is to optimize the characteristics in order to increase the power of the wind power installation. The mathematical model of the wind turbine operation makes it possible to perform such optimization with high reliability. The complexity of the practical application of the mathematical model of the wind generator is that the processes occurring are described by a system of differential and nonlinear equations containing a large number of parameters [1-6]. And yet, in order to verify the correctness of the simulation, it is necessary to manufacture a prototype wind turbine and conduct certain tests.

\section{PARAMETERS OF THE MATHEMATICAL MODEL}

The calculation performed using the "Aerodinama" software was used for testing [7]. Get acquainted with the calculation by the link [8].

The following parameters were selected for the calculation:

- Net Power: $400 \mathrm{~W}$

- Average annual wind speed: $3.5 \mathrm{~m} / \mathrm{s}$

- Maximum wind speed (storm): $25 \mathrm{~m} / \mathrm{s}$

- Number of blades: 3 pcs

- Mast height: $15 \mathrm{~m}$

- Starting moment of the generator: $0.49 \mathrm{~N} \cdot \mathrm{m}$

- Generator efficiency: $80 \%$

- Direction of rotation: Right

- Profile type: BRUXEL 36

As a result of aerodynamic calculation, the following parameters of the wind turbine have been obtained:

- Diameter of wind turbine: $2.55 \mathrm{~m}$

- Wind power utilization: 0.46

- Starting wind speed: $1.5 \mathrm{~m} / \mathrm{s}$

- Turnovers at rated wind speed: $340 \mathrm{rpm}$

- Revolutions at maximum wind speed: $1412 \mathrm{rpm}$

- Estimated torque on the generator shaft: $11.2 \mathrm{~N} \cdot \mathrm{m}$

- Storm torque on the generator shaft: $193.3 \mathrm{~N} \cdot \mathrm{m}$

- Estimated force of frontal pressure on the wheel: $170 \mathrm{~N}$

- Frontal force with maximum gust: $12.14 \mathrm{kN}$

- Wind turbine power during a storm: $28.58 \mathrm{~kW}$

The design characteristics of the turbine impeller, obtained in the form of graphs (fig. 1): 

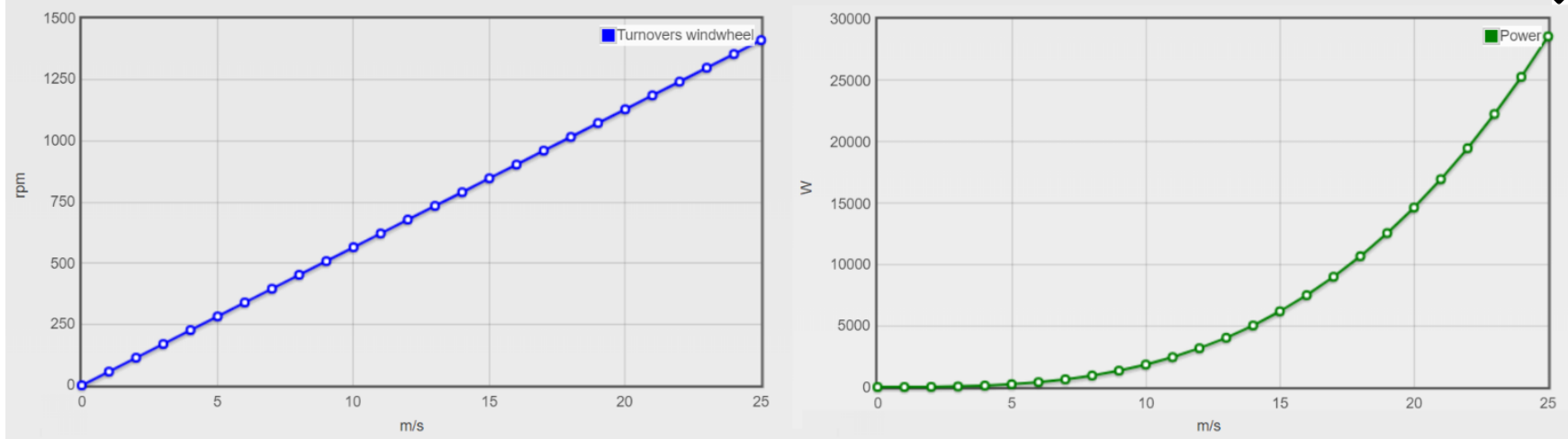

Fig. 1. The design characteristics of the turbine impeller

A cloud of points has also been obtained describing the blade model in the coordinate system centered on the working shaft of the wind turbine. The point cloud was loaded into the SolidWorks software package and a 3D model of the blade was built (fig. 2a). Using the drawing function from the model in the SolidWorks software package, drawings have been obtained for the manufacture of a wind turbine (fig.2b):

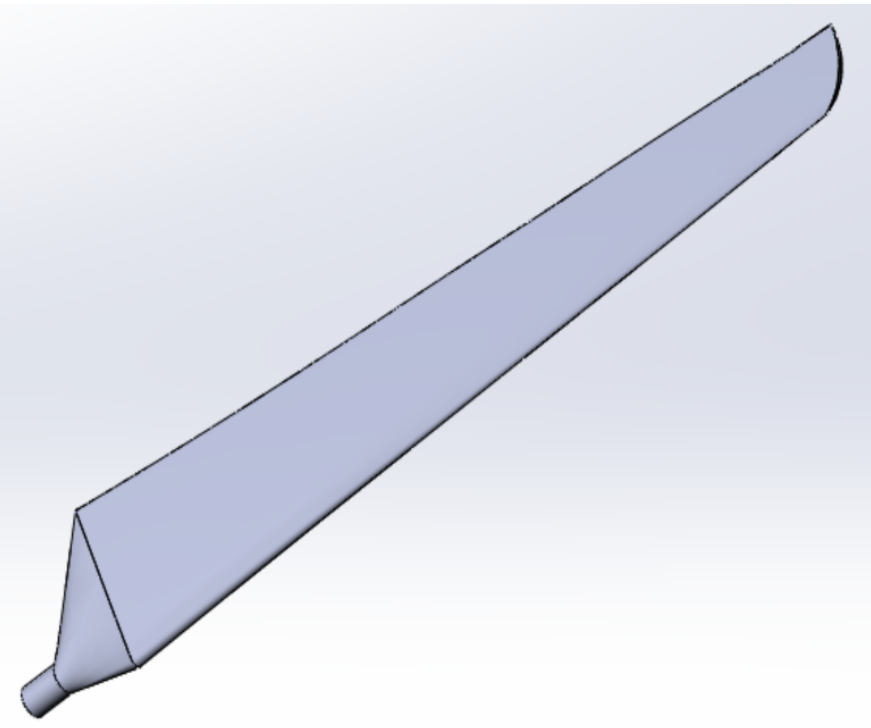

a)
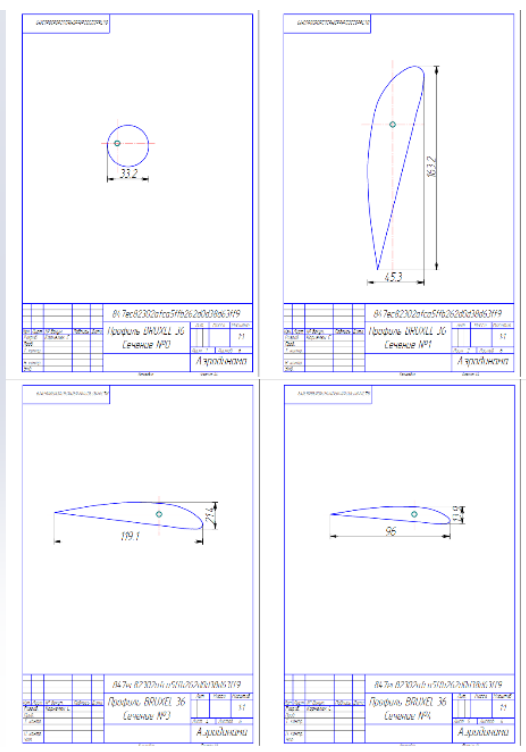

b)

Fig. 2. 3D model and drawings of a wind turbine blade.

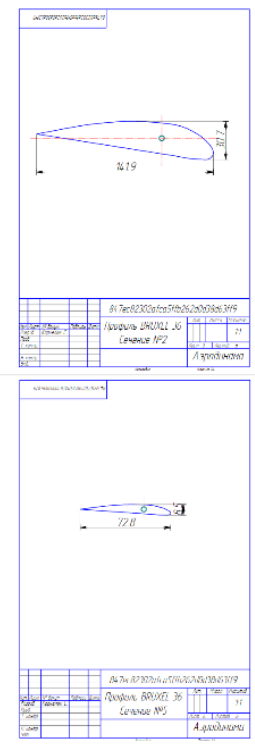

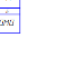




\section{MEASUREMENT TOOLS}

The basis for the measurement tool - logger, is the Arduino Nano microcontroller board version 3.0. The following are the block installation diagram and the appearance of the device. (fig. 4).
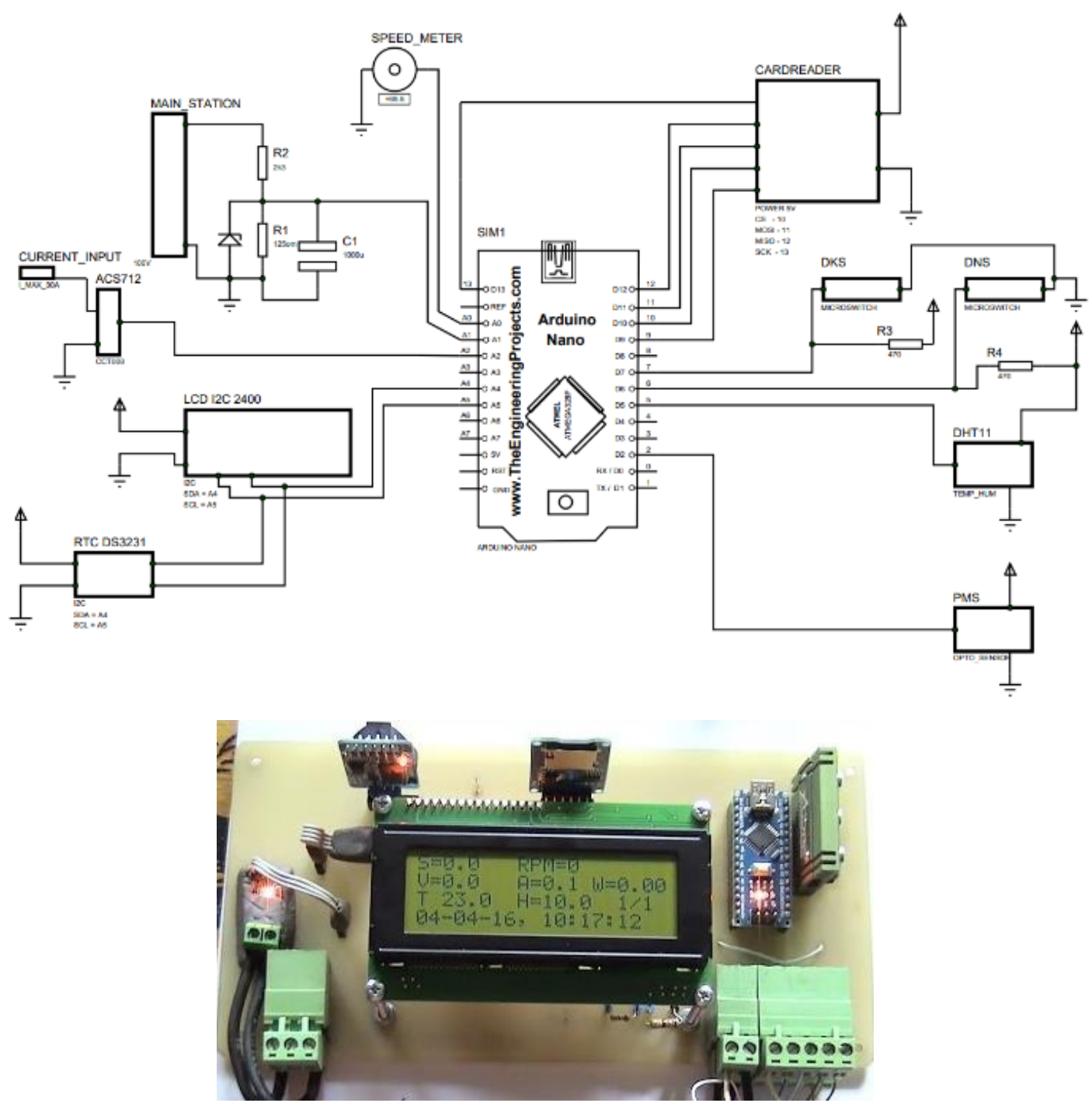

Fig. 4. Assembly block diagram and appearance of the logger.

The data were saved to a memory card using the Micro SD SPI module. With an interval of 1 second, the following data were recorded:

- Turnovers of a working shaft of the screw, rpm

- Wind speed, $\mathrm{m} / \mathrm{s}$

- Voltage at the output of the rectifier unit, $\mathrm{V}$

- Rectifier output current, A

- Power, W

- The temperature of the winding of the generator, ${ }^{\circ} \mathrm{C}$

- Date

- Time

Turnovers were measured using a Hall Sensor Module KY-003 Hall with 6 magnetic contactors. Wind speed was measured using an analog anemometer with an electromagnetic system based on the output voltage level. The voltage at the output of the rectifier unit was measured using a voltage divider. The current was measured using an ACS712 30 A sensor. The temperature of the generator windings was measured with a DS18B20 sensor.

The data were saved in a file format txt as a string with a separator | (vertical bar), each new record was separated from the previous one through the end of line symbol. Also, the current state of the wind turbine was displayed.

\section{DATA PROCESSING}

For convenience of processing, the data were placed in the EXCEL program. In Figure 5, a fragment of the file is shown. 


\begin{tabular}{|c|c|c|c|c|c|c|c|c|c|c|}
\hline 4 & A & B & C & D & $E$ & $\mathrm{~F}$ & G & \multirow{3}{*}{$\frac{H}{\frac{H}{\text { Time }}}$} & \multirow[t]{2}{*}{1} & \multirow[t]{2}{*}{$J$} \\
\hline 1 & Turno & s Wind & Voltage & Ampe & E Watts & Temp & late & & & \\
\hline $206^{\prime}$ & 140 & 2,34 & 13,67 & 2,91 & 39,79 & 23,25 & 21.09 .2016 & & & \\
\hline 207 & 150 & 2,54 & 13,67 & 2,39 & 32,71 & 23,25 & 21.09 .2016 & $17: 49: 30$ & & \\
\hline 208 & 140 & 2,44 & 13,67 & 2,54 & 34,73 & 23,25 & 21.09 .2016 & $17: 49: 31$ & & \\
\hline $209^{\prime}$ & 140 & 2,44 & 13,67 & 2,32 & 31,7 & 23,25 & 21.09 .2016 & $17: 49: 32$ & & \\
\hline $210^{\prime}$ & 140 & 2,54 & 13,67 & 2,47 & 33,72 & 23,31 & 21.09 .2016 & $17: 49: 33$ & & \\
\hline 211 & 150 & 2,73 & 13,67 & 2,76 & 37,77 & 23,31 & 21.09 .2016 & $17: 49: 34$ & & \\
\hline 212 & 140 & 2,83 & 13,67 & 3,06 & 41,81 & 23,31 & 21.09 .2016 & $17: 49: 35$ & & \\
\hline $213^{\prime}$ & 150 & 3,22 & 13,67 & 2,99 & 40,8 & 23,31 & 21.09 .2016 & $17: 49: 37$ & & \\
\hline $214^{\prime}$ & 150 & 2,83 & 13,67 & 3,36 & 45,86 & 23,31 & 21.09 .2016 & $17: 49: 38$ & & \\
\hline $215^{\circ}$ & 160 & 3,81 & 13,67 & 3,21 & 43,83 & 23,31 & 21.09 .2016 & $17: 49: 39$ & & \\
\hline 216 & 150 & 3,71 & 13,76 & 3,8 & 52,29 & 23,31 & 21.09 .2016 & $17: 49: 40$ & & \\
\hline $217^{\prime}$ & 160 & 3,42 & 13,76 & 4,02 & 55,35 & 23,31 & 21.09 .2016 & $17: 49: 41$ & & \\
\hline 218 & 160 & 2,73 & 13,76 & 3,8 & 52,29 & 23,31 & 21.09 .2016 & $17: 49: 42$ & & \\
\hline
\end{tabular}

Fig. 5. Log file fragment.

In the above example, it is seen that the values of wind speed and speed or power do not have a clear and direct relationship. For example, we can see that $150 \mathrm{rpm}$ in lines 207, 211, 213 and 214 correspond to different readings of wind speed 2.54, 2.73, 3.22 and 2.83. This difference in readings is due to the inertia of the mechanical system of the wind turbine.

However, the variation in wind speed readings has a small range, which allows for a large enough plot to build graphs of wind turbine speed dependence on wind speed. Based on the fact that when building graphs, the power is indicated as a mechanical quantity, and in the data log it is an electrical parameter, we do not take into account the power graph for comparing the results.

A data log was processed in Microsoft EXCEL software and a graph of wind turbine speed versus wind speed was plotted. Fig. 6 shows a graph of the processed data in comparison with the calculated parameters.
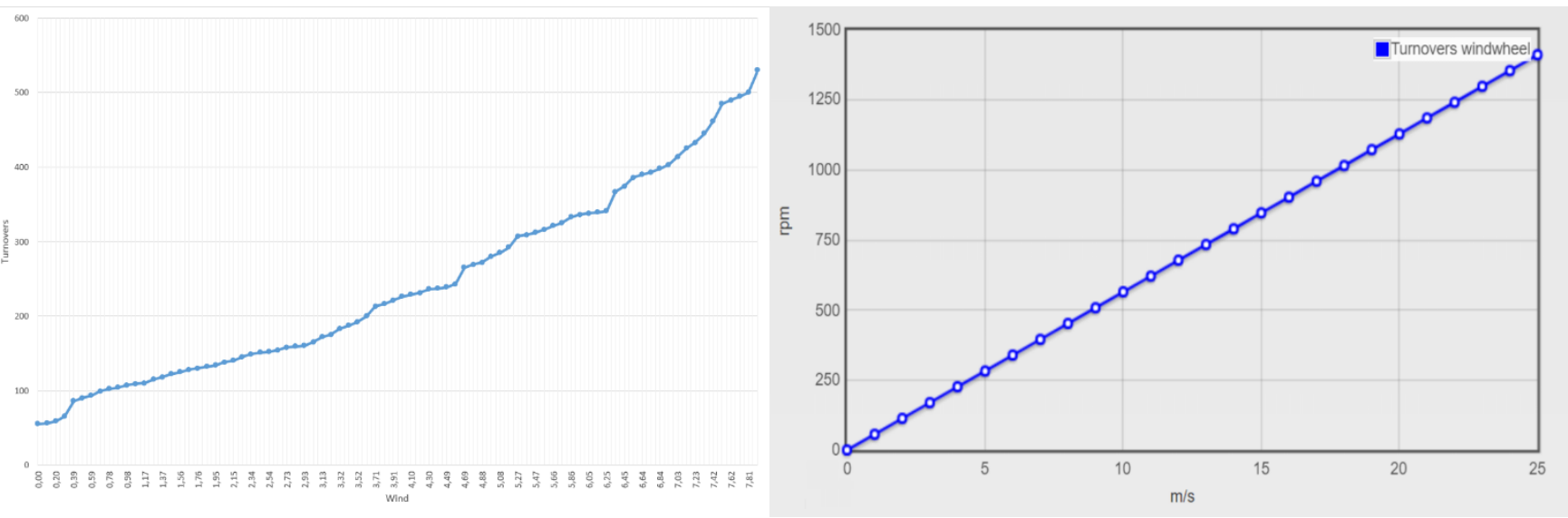

Fig. 6. Graph of wind turbine speed versus wind speed processed and calculated.

The insignificant non-linearity of the graph in the figure to the left is explained by the influence of the electrical load on the generator operation, which, in turn, gives an additional load to the wind wheel. However, it can be clearly seen on the graphs that the data obtained correspond to the calculated parameters.

\section{CONCLUSIONS}

The experiment conducted on the created $400 \mathrm{~W}$ wind turbine installed unit confirmed the validity of the mathematical model used in the "Aerodinama" software package [7]. The reliability of the model is confirmed by a comparison of the calculated and experimental performance data obtained during the tests of the wind power installation.

The errors of the mathematical model are associated with the neglect of additional parameters that affect the operation of the wind turbine. These parameters include the effect of the consumption of electric energy on the rotational speed of the wind wheel.

\section{REFERENCES}

[1] Y. Shefter, "Wind power units", Moscow: Mechanical engineering, p. 49, 1972.

[2] J. F. Manwell, J. G. McGowan, A. L. Rogers "Wind Energy Explained:Theory, Design, and Application Second Edition", John Wiley \& Sons, Ltd, p. 689, 2009.

[3] Y. Fateev "Wind engine and wind turbine", OGIZ-SELKHOZGIS, p. 79, 1948.

[4] A. Yakovlev, M. Zatuchnaya, V. Merkushev and V. Pashkov, "Calculation and design of wind power installations with a horizontalaxis wind turbine and a permanent-magnet synchronous generator", Tutorial on course design, Kharkiv: National Aerospace University "Khark. Aviat. Un-ty", p, 125, 2003.

[5] V. Krivtsov, A. Oleynikov, A. Yakovlev "Inexhaustible energy Book 1 Wind power generators", Coursebook, Kharkiv: National Aerospace University "Khark. Aviat. Un-ty", Sebastopol: Sebast. nat. tech. Unty, p. 400, 2003. 
A. Yakovlev, M. Zatuchnaya, "Construction of power characteristics of wind turbines with optimal profiles of working blades", Renewable energy of the XXI century: materials of the 10th anniversary international scientific conference, Crimea, Mykolaivka, 14-18 Sept. 2009, pp. 255-260, 2009.

[7] S. Korneliuk. "Aerodinama - mathematical model of the wind turbine WPI”, “Lighting engineering and electric power” №3 (50) 2017. pp. $42-48,2017$.
[8] S. Korneliuk "Aerodinama" [Electronic source] - URL: https://seiger.pp.ua/aerodinama/847ec82302afca5ffb262d0d38d63ff9

[9] Sabinin G.KH. The problem of using wind energy. Part 6. Theory and aerodynamic calculation of windmills. Proceedings Central Aerohydrodynamic Institute issue number 104-Moscow, 1931. - P. 70 .

\section{Експериментальне підтвердження математичної моделі вітротурбіни ВЕУ}

\author{
С.I. Корнелюк \\ ХНУМГ ім. О.М. Бекетова \\ Україна
}

\author{
П. Дмітрієв \\ Мсждуреченськ \\ Росія
}

\author{
Д.В. Тугай \\ ХНУМГ ім. О.М. Бекетова \\ Україна
}

Експериментальне підтвердження математичних моделей, це один з аспектів наукового процесу. У даній статті розглянута постановка експерименту з вітряною турбіною, яку побудовано з використанням математичної моделі, описаній в [7, 9] i реалізованої у вигляді програмного комплексу "Аеродинама" [8].

Програмний комплекс "Аеродинама", реалізує розрахунок згідно "Теорії реального вітряка" представленої проф. Г.Х. Сабінін в [9]. Згідно результатів розрахунку було отримано геометричні параметри турбіни, а також отримані конструкторські креслення. Далі було виготовлено та встановлено в реальних природних умовах фізичну модель вітротурбіни. Для ВЕУ було обрано та виготовлено генератор на постійних магнітах, потужністю 400 Вт. ККД генератора прийнято 80\%. Для ротора ВЕУ використовувався трилопатевої гвинт 3 профілем лопатей BRUXEL 36. Середньорічна швидкість вітру прийнята як 3,5 м/с, а максимальна - $25 \mathrm{~m} / \mathrm{c}$.

Для контролю показників ВЕУ, було розроблено логер на базі плати мікроконтролера Arduino Nano версії 3.0 і набору декількох датчиків. А саме датчика Хола KY-003 Hall, датчика ACS712 30A і датчика DS18B20. Швидкість вітру вимірювалася за допомогою аналогового анемометра $з$ електромагнітної системою, і контролювалася за рівнем напруги на виході. Поточні дані збиралися на карті пам'яті і дублювалися на дисплей. Крок вимірів - 1 сек. Відстежувалися такі дані: швидкість вітру; оберти робочого вала ВЕУ; напруга на виході блоку випрямляча; струм на виході випрямляча; потужність і температура генератора.

Зібрані дані було імпортовано в програмний комплекс MS EXCEL. Результати обробки даних представлено у вигляді графіків.

Отримані експериментальні дані підтверджують точність алгоритму, обраного для розробки математичної моделі.

Ключові слова - аеродинама, вітрова турбіна, лопать, математична модель, алгоритм розрахунку, експеримент, логер. 